\title{
Analisa Teknis dan Ekonomis Perbaikan Controllable Pitch Propeller (CPP) Kapal KM. Dharma Kencana 3611 GRT
}

\author{
Suharto*, Sulaiman \\ Departemen Teknologi Industri, Sekolah Vokasi Universitas Diponegoro, \\ Jl. Prof. Soedarto, SH, Kampus Undip Tembalang, Semarang, Indonesia 50275 \\ *E-mail: suharto2008@ymail.com
}

Diterima: 26-03-2021; Direvisi: 31-03-2021; Dipublikasi: 27-04-2021

\begin{abstract}
Abstrak
Baling-baling adalah bagian penting dari kapal. Stabilitas, usia pemakaian dan biaya pemakaian memiliki peran penting dalam pemilihan propeller. Pengaruh modifikasi juga ditinjau dari pengaruh penambahan ketebalan material propeller, pada sistem propulsi kapal yang berpengaruh terhadap performa propeller kapal serta hubunganya terhadap biaya reparasi perbaikan dari propeller. Tujuan penelitian ini, menganalisis desain propeller untuk direparasi dan biaya pereparasian propeller untuk mendapatkan performa terbaik dari mesin penggerak propeller sehingga merepresentasikan perbandingan kinerja dari propeller sebelum dan sesudah redesain. Simulasi perhitungan dengan metode finite elemen berbasis persamaan matematik yang menggambarkan karakteritik hidostatik propeller. Perencanaan dan pengunaan material sangat menentukan kekuatan dari proses perbaikan propeller memerlukan perencanaan yang tepat dari segi desain dan material yang akan digunakan. Metode perhitungan dengan numerik ini membantu dalam merekonstruksi desain awal propeller yang telah mengalami kerusakan. Saat putaran propeller pada rpm mesin yang optimum tegangan terjadi pada daun propeller. Hasil analisa menunjukan desain baru dapat memberikan nilai tambah rata-rata $0,24 \%$ untuk nilai $L / D_{T}$ dan terhadap nilai nilai $\mathrm{D}_{\mathrm{a}} / \mathrm{D}_{\mathrm{f}}$ memiliki nilai tambah rata-rata $0,46 \%$. Sementara biaya proses manufaktur dapat berkurang sebesar $38 \%$ karena waktu produksi dan penyesuaian yang tidak terulang ulang kembali.
\end{abstract}

Kata kunci: CPP; ekonomis; propelle; reparasi; teknis

\begin{abstract}
Propeller is an essential part of the ship. Stability, service life and cost of use have an important role in propeller selection. The effect of modification is also viewed from the effect of increasing the thickness of the propeller material, on the ship's propulsion system which affects the performance of the ship's propeller and its relation to the cost of repairing the repairs of the propeller. The purpose of this research is to analyze the propeller design to be repaired and the cost of propeller repair to get the best performance from the propeller engine so that it represents the comparison of the performance of the propeller before and after redesign. The calculation simulation uses the finite element method based on mathematical equations that describe the hydostatic characteristics of the propeller. Planning and the use of materials will determine the strength of the propeller repair process, requiring proper planning in terms of design and materials to be used. This numerical calculation method assists in reconstructing the initial design of a damaged propeller. When the propeller rotates at the optimum engine rpm, the stress occurs on the propeller blade. The results of the analysis show that the new design can provide an average added value of $0.24 \%$ for the L / DT value and the Da / Df value has an average added value of $0.46 \%$. Meanwhile, the cost of the manufacturing process was reduced by $38 \%$ due to the production time and adjustments that were not repeated.
\end{abstract}

Keywords: CPP; economical; propeller; repair; technical

\section{Pendahuluan}

Baling-baling adalah bagian penting dari kapal. Stabilitas, usia pemakaian dan biaya pemakaian memiliki peran penting dalam pemilihan baling-baling [1,2]. Secara konvensional, dari satu abad ke belakang baling-baling dibuat dengan baja, aluminium, besi tuang dan setelah beberapa penelitian berpendapat penggunaan paduan untuk balingbaling seperti paduan $\mathrm{Al}$, paduan $\mathrm{Cu}$, dan di antara mereka, paduan yang banyak digunakan adalah $\mathrm{NAB}$ dan MAB [3,4]. Dari beberapa dekade terakhir dunia material lebih tertarik pada bahan komposit karena kelebihannya berbiaya rendah, tahan lama dan kekuatan yang cukup kaku, penelitian tentang propulsi juga mengalihkan fokusnya dan mulai mengadopsi material komposit untuk berbagai bagian kapal seperti drive shaft, hull, dan propeller [5,6]. Selain itu 
hidrodinamika baling-baling telah diteliti selama beberapa dekade terakhir, karena aplikasi industri dan kegunaan dalam bidang maritim yang luas, seperti kegiatan untuk sarana transportasi contohnya pada kapal tanker dan kapal penyeberangan, kapal perintis seperti terlihat pada Gambar 1 [7,8]. Gambar 1 menunjukan kerusakan pada propeller kapal, tegangan yang terjadi pada baling-baling tipe $C P P$ cukup membuat material mengalami kegagalan. Sebagai perangkat propulsi yang paling banyak digunakan,baling-baling dilengkapi dengan efisiensi tinggi, ketahanan dan stabilitas $[9,10]$. Banyak jenis baling-baling khusus telah dikembangkan berdasarkan perrencanaan desain baling-baling biasa untuk berbagai kondisi kerja, seperti baling-baling controllable pitch [11], baling-baling ducted [12] , balingbaling kontra-berputar koaksial [13] dan baling-baling tandem [2] .
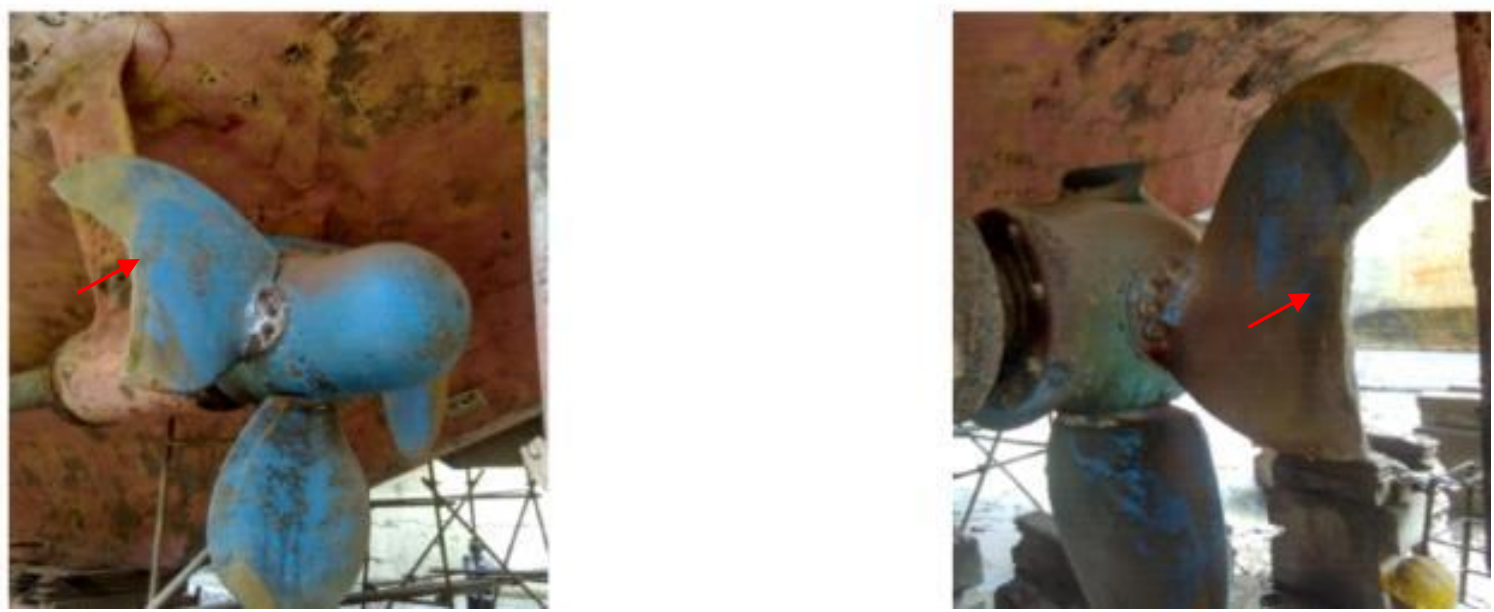

Gambar 1. Kerusakan pada propeller CPP

Hasil penelitian terdahulu pada artikel "Numerical investigation on the flow characteristics and hydrodynamic performance of tandem propeller" menunjukkan bahwa gaya hidrodinamik memaksimalkan pada rasio jarak kurang dari 0,30 jika rasio diameter sama dengan 1,0. Juga ditemukan bahwa efisiensi ditingkatkan sekitar $45 \%$ untuk balingbaling tipe fixied dengan rasio diameter 0,95 pada $\mathrm{L} / \mathrm{D} \mathrm{f}=0,29$, dibandingkan dengan baling-baling tunggal, pada $\mathrm{J}=$ 0,7. Selain itu, dengan menentukan rasio jarak atau rasio diameter secara tepat, putaran baling-baling belakang dapat dengan baik menyerap energi dari pusaran sudut trailing dari baling-baling depan. Akibatnya, pusaran yang tertinggal dengan cepat menghilang dan menghilang di bidang bangun setelah penggabungan, dan kinerja hidrodinamik yang lebih baik dapat diperoleh [14]. Senada dengan hal terbut penelitian sebelumnya pada artikel "Deformation behavior of a surface composition of materials with shape memory effect in the conditions of multi-factor impacts" menjelaskan suatu rekomendasi tentang pilihan struktur dangeometri komposisi multifungsi. Berdasarkan analisis tegangan-regangan baling-baling dengan lapisan komposit multifungsi "baja J91171-Ni-TiNiZr-TiNiCo", menunjukan kemanfaatan komposisi permukaan yang terbuat dari bahan komposit. Fungsi dari paduan ini untuk meningkatkan keandalan fungsionaliti produk. Hasilnya memberikan peningkatan daya tahan, peningkatan keausan dan daya tahan sambil mengurangi biaya perbaikan [15]. Jika ditinjau dari bahan material pada paper dengan judul "A review on materials used for marine propellers"menunjukan hasil baling-baling dengan jumlah bilah yang bervariasi dengan tetap dan pitch terkontrol yang memiliki diameter berbeda dan sudut kemiringan yang akan ditinjau. Metode yang digunakan dengan simulasi struktur, simulasi fluida, Metode Finite Elemen, Studi Kasus CFD, Kavitasi, uji keausan erosi, analisis sambungan puntir bengkok dan struktur fluida, simulasi dengan pengujian perairan terbuka dan tertutup [7,9]. Hasilnya 
menunjukan komposit fiberglass terbukti ekonomis dan berkinerja lebih baik dan dapat beradaptasi dalam sudut pandang ekonomis. Baling-baling komposit serat karbon memiliki keunggulan lebih dari yang lain pada kasus tertentu. Studi terbaru difokuskan pada pemanfaatan material komposit hibrida untuk baling-baling sebagai keserbagunaannya dalam mencapai hasil yang baik [16]. Kinerja fluida dengan pendekatan persamaan Navier Stokes dan persamaan kontinuitas, dapat ditulis dalam bentuk tensor Cartesian [4] sesuai dengan Pers. (1).

$$
\frac{\delta(\rho u)}{\delta x}+\frac{\delta(\rho v)}{\delta y}+\frac{\delta(\rho w)}{\delta z}=0
$$

dimana dalam persaman 1 tersebut, $\mathrm{x}, \mathrm{y}$ dan $\mathrm{z}$ adalah koordinat Cartesian dan $\mathrm{u}, \mathrm{v}$ dan $\mathrm{w}$ adalah komponen kecepatan yang sesuai. $\rho$ adalah densitas, $p$ adalah tekanan, gaya benda sehingga terjadinya tegangan viskositas. Kemudian jika menggunakan persamaan RANS model [5], dapat ditulis ulang sesuai dengan Pers. (2).

$$
\frac{\partial}{\partial x_{j}}\left(\rho \bar{u}_{i} \bar{u}_{j}\right)=-\frac{\partial \bar{p}}{\partial x_{i}}+\frac{\partial}{\partial x_{j}}\left[\pi\left(\frac{\partial \bar{u}_{j}}{\partial x_{j}}+\frac{\partial \bar{u}_{i}}{\partial x_{i}}\right)-p \overline{\bar{u}_{\imath}^{\prime} u_{j}^{\prime}}\right]
$$

Dalam persamaan ini - $\rho u u^{\prime}{ }^{\prime} i j$ menggambarkan tegangan Reynolds. Sedangkan pada perhitungan hidrodinamika Kinerja hidrodinamik dari baling-baling tandem bisa jadi dievaluasi dengan beberapa koefisien non-dimensi, yaitu koefisien dorong KT, koefisien torsi KQ dan efisiensi n0. Pada saat ini studi, formula standar ITTC (International Towing Tank Conference) [6], ditentukan dengan menggunakan pendekatan Pers. (3-6).

$$
\begin{aligned}
& J=\frac{V_{A}}{n_{f} D_{f}} \\
& K_{T f}=\frac{T_{f}}{\rho n_{f}^{2} D_{f}^{4}} \\
& K_{Q f}=\frac{Q_{f}}{\rho n_{f} D_{f}^{5}} \\
& K_{T a}=\frac{T_{a}}{\rho n_{a}^{2} D_{a}^{2}}
\end{aligned}
$$

Dalam persamaan tersebut, nilai $V_{A}$ adalah kecepatan gerak maju dalam $[\mathrm{m} / \mathrm{s}], \mathrm{T}$ dan $\mathrm{Q}$ adalah gaya dorong dan torsi propeller masing-masing dalam $[\mathrm{N}]$ dan $[\mathrm{N} \cdot \mathrm{m}] . \mathrm{n}$ adalah putaran kecepatan dalam [rps] dan D adalah diameter balingbaling dalam [m]. Subskrip 'f' mewakili baling-baling depan dan 'a' menunjukkan baling-baling belakang. Adapun gap dari penelitian sebelumnya perlunya uji numerik untuk suatu desain propeller sehingga menentukan karakter hidrodinamiknya. Sedangkan pengaruh penggunaan tipe material berpengaruh terhadap hasil kekuatan propeller ketika beroperasi dan menhasilkan bentuk surface dari daun propeller yang memiliki karakter tersendiri. Sehingga dalam penelitian ini menghubungkan nilai numerik dengan karakter materialnya yang diaplikasikan pada performa propeller kapal ro-ro seberat 3611 GRT .Korelasi dan hubungannya dengan penelitian terdahulu tersebut cukup terlihat dari penelitian ini adalah proses perbaikan propeller tipe $C P P$ berserta perubahan desain pada bagian propeller setelah perbaikan. Pengaruh modifikasi juga ditinjau dari pengaruh penambahan ketebalan material propeller, pada sistem propulsi kapal yang berpengaruh terhadap performa propeller kapal serta hubunganya terhadap biaya reparasi perbaikan dari propeller. Hal ini merumuskan suatu hipotesis bahwa perencanaan desain propeller dapat mempengaruhi waktu kierja manufaktur proses reparasi. Demikian halnya dengan penelitian - penelitian yang dilakukan sebelumnya berkaitan dengan eksperimen simulasi modifikasi desain dan material pada propeller kapal.

Secara garis besar batasan masalah dalam penelitian ini adalah bagian yang dilakukan modifikasi perbaikan propeller pada kedua sistem propulsi, perhitungan simulasi desain propeller dengan Finite Element Methode, kondisi gelombang sesuai dengan kondisi rata-rata perairan dalam di Indonesia, cuaca ketika pelaksaan sea trial cukup cerah. 
Suharto dkk /Jurnal Rekayasa Mesin

p-ISSN: 1411-6863, e-ISSN: 2540-7678

Vol.16|No.1|123-131|April|2021

Sehingga berdasarkan pendahuluan dan beberapa kajian dari peneliti terdahulu maka tujuan dari penelitian ini adalah menganalisis desain propeller untuk direparasi dan biaya pereparasian propeller untuk mendapatkan performa terbaik dari mesin penggerak propeller sehingga merepresentasikan perbandingan kinerja dari propeller sebelum dan sesudah redesain.

\section{Material dan metodologi}

Data kapal yang digunakan dalam penelitian ini, terdapat pada data Tabel 1. Data propeller kapal dengan kerusakannya tergambar pada Gambar 2. Alur metode yang digunakan adalah dengan menggamabar ulang desain propeller model CPP untuk kemudian dilakukan simulasi perhitungan dengan metode finite elemen. Kemudian dibandingkan dibuat model perbaikan berdasarkan desain yang telah di buat. Seperti terlihat pada Gambar 3, dapat terlihat alur penelitian dimana desain yang dibuat kemudian dibuat dan disimulasikan sebelum di produksi untuk dibuat.

Tabel 1. Data ukuran utama kapal

\begin{tabular}{lll}
\hline No & Data Ukuran Kapal & \\
\hline 1 & Nama Kapal & KM. Dharma Kencana \\
2 & LOA & $88,91 \mathrm{~m}$ \\
3 & LPP & $84 \mathrm{~m}$ \\
4 & B & $15,08 \mathrm{~m}$ \\
5 & T & $3,7 \mathrm{~m}$ \\
6 & GRT & 3611 Ton \\
\hline
\end{tabular}

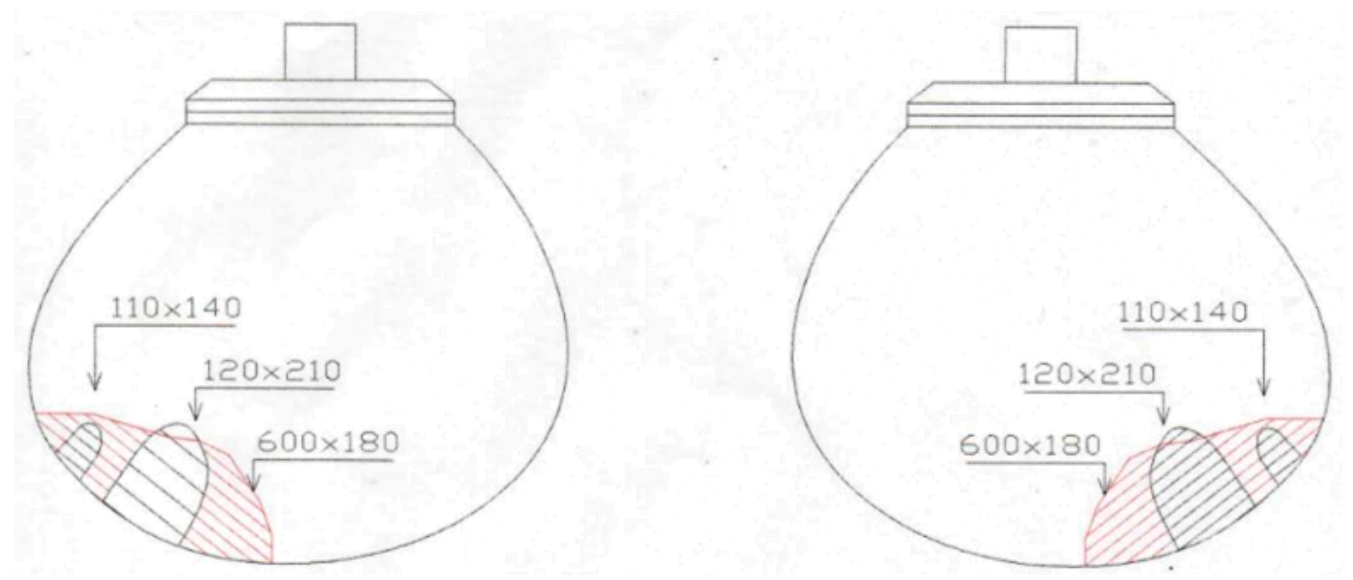

(a)

(b)

Gambar 2. Data record pada propeller CPP yang mengalami kerusakan, (a) sisi muka dan (b) sisi belakang

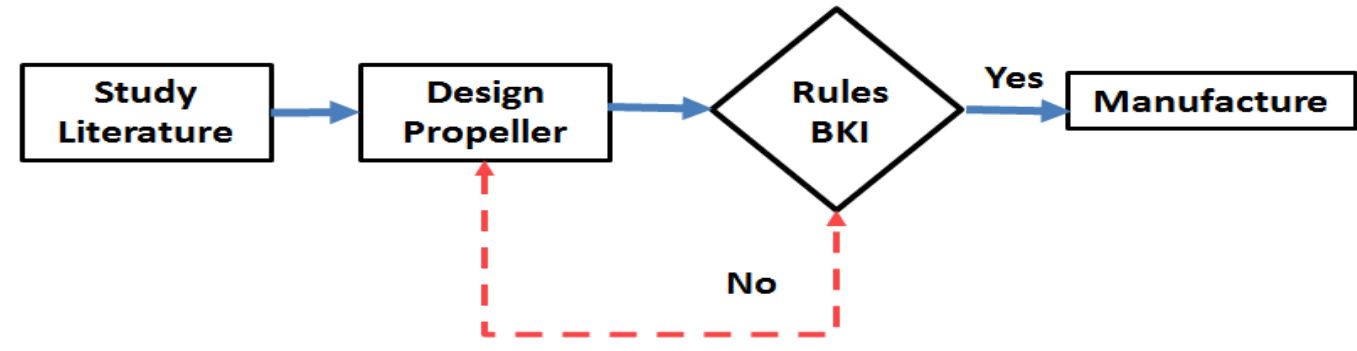

Gambar 3. Alur penelitian 
Suharto dkk /Jurnal Rekayasa Mesin

p-ISSN: 1411-6863, e-ISSN: 2540-7678

Vol.16|No.1|123-131|April|2021

\section{Hasil dan pembahasan}

Hasil pemodelan kemudian dianalisa dan didapatkan nilai tegangan pada bagian face propeller setiap daunnya memiliki nilai maksimum sebesar $130 \mathrm{Mpa}$ untuk CPP kanan dan $140 \mathrm{Mpa}$ untuk CPP kiri pada kondisi operasional yang menyesuaiakan dengan daa maksimum rpm mesin. Dikarenakan data pada beban maksimum merupakan baban kinerja tertinggi pada propeller, dapat dilihat pada Gambar 4.

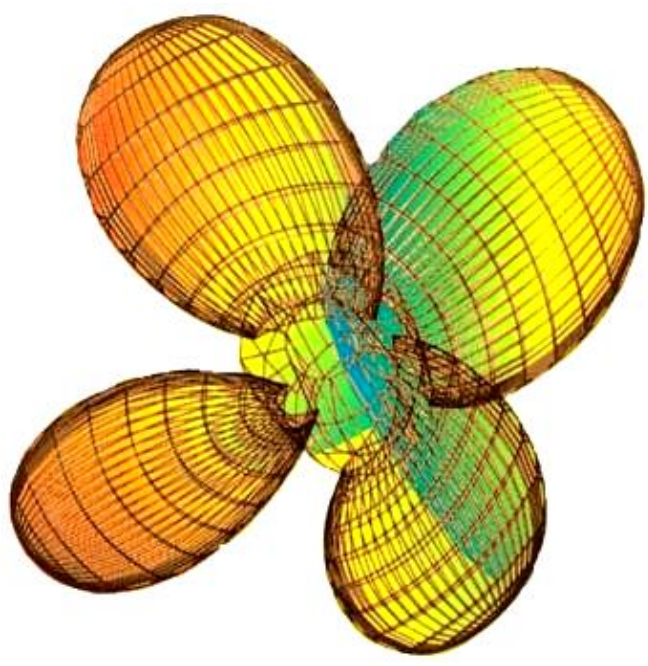

(a)

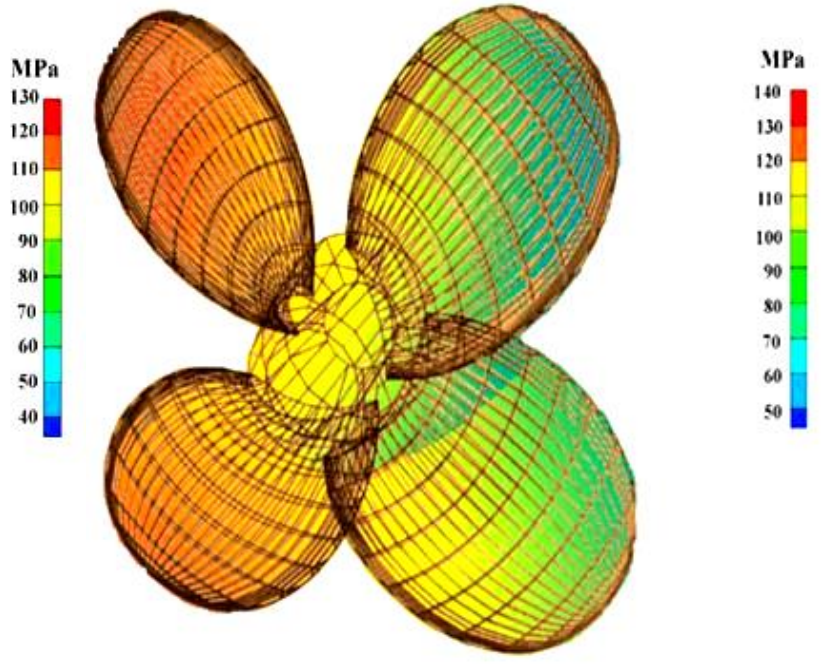

(b)

Gambar 4. Tegangan maksimum pada desain propeller, (a) CPP kanan dan (b) CPP kiri

Dari Pers. (1) kemudian dilakukan perhitungan untuk menentukan dan menggambarkan kondisi performa propeller setelah didesain, kemudian dibandingkan dengan persamaan 3,4,5,6 masing-masing sesuai perbandingannya untuk memperoleh perbandingan, seperti terlihat pada Gambar 5 dan 6. Dari Gambar 5 diketahui nilai perbandingan antara desain baru dan awal memiliki perbedaan rata-rata $0,24 \%$ untuk nilai $L / D_{T}$ sedangkan untuk nilai $D_{a} / D_{f}$ pada Gambar 6, memiliki nilai perbedaan rata-rata $0,46 \%$ Kemudian dilakukan proses reparasi / manufaktur sesuai dengan rekonstruksi desain yang telah ditentukan.

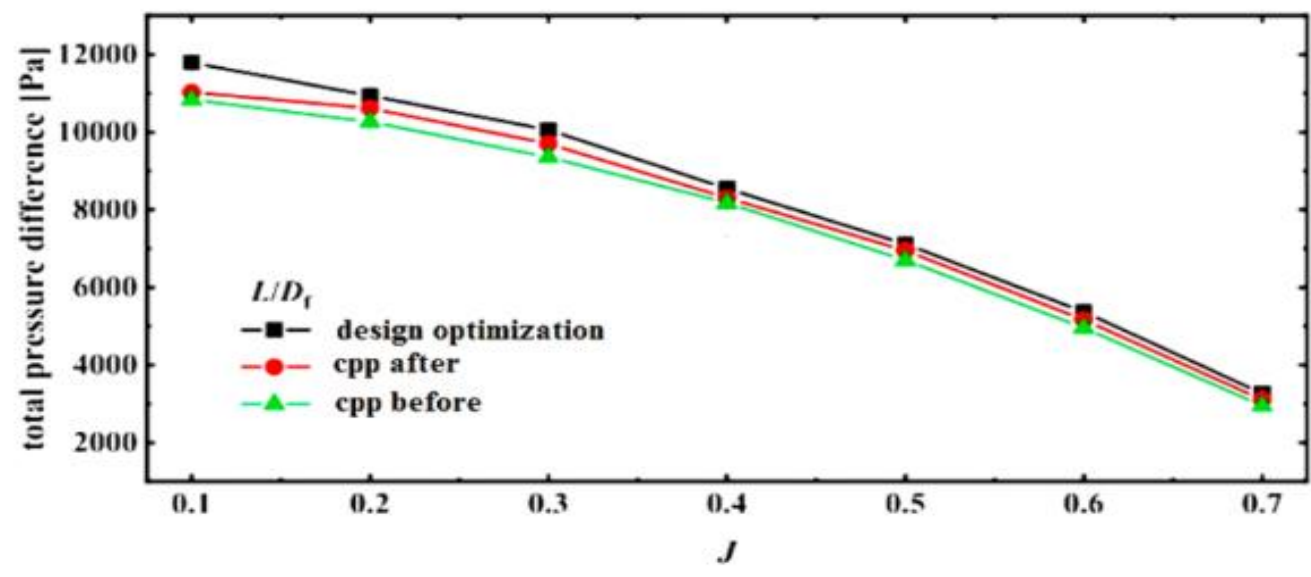

Gambar 5. Perbandingan nilai tegangan terhadap L / $\mathrm{D}_{\mathrm{f}}$ 
Suharto dkk /Jurnal Rekayasa Mesin p-ISSN: 1411-6863, e-ISSN: 2540-7678

Vol.16|No.1|123-131|April|2021

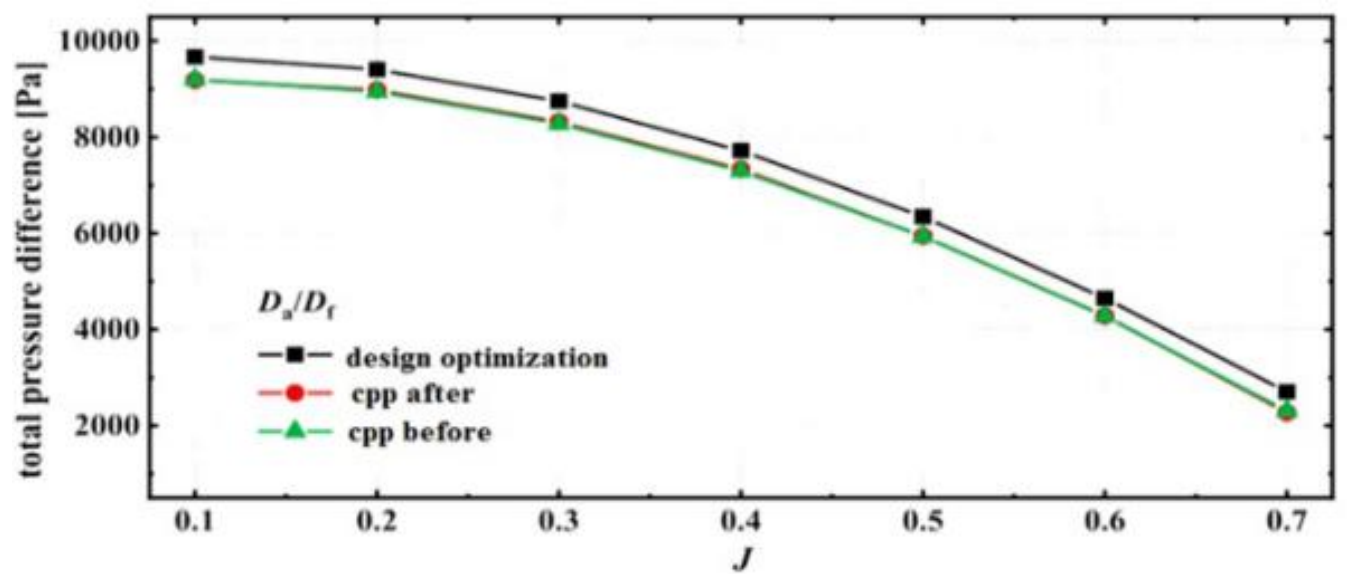

Gambar 6. Perbandingan nilai tegangan $D_{a} / D_{f}$

Terlihat pada Gambar 7, menunjukan pesoses pelurusan pada bagian propeller yang bengkok atau mengalami deformasi. pelurusan bagian yang bengkok dan sebagian patah ini menggunakan heat treatmen sehingga material dapat menjadi lunak dan mudak diatur. Kemudian setelah diluruskan maka dilakukan peroses pengelasan secara bertahap sehingga membentuk daun propeller yang diinginkan. Proses pengelasan dengan teknik pengelasan Oxyaceteline dimana elektroda atau material tambahan yang digunakan adalah manganese-bronze dengan unsur utama 58,5 $\mathrm{Cu} ; 39,2$ $\mathrm{Zn} ; 1,0 \mathrm{Fe} ; 0,3 \mathrm{Mn}$, lihat Gambar 8 (a). Proses pengecekan setelah perbaikan dilakukan dengan metode Non Destructive Test yaitu dengan menggunakan Dry Penetran Test, seperti terlihat pada Gambar 8 (b).

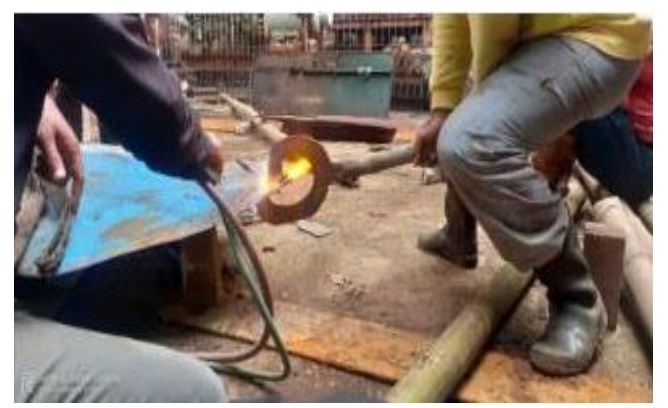

Gambar 7. Proses perbaikan daun propeller CPP

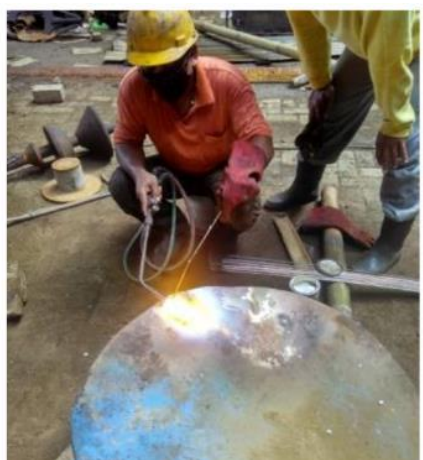

(a)

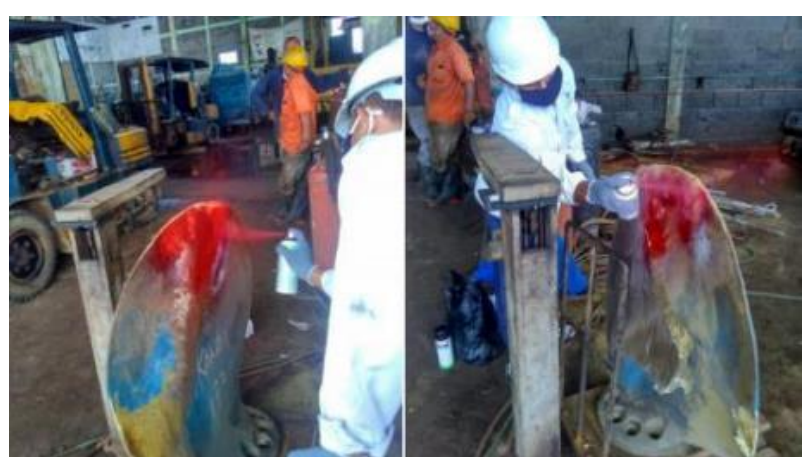

(b)

Gambar 8. (a) Proses pengelasan daun propeller CPP dan (b) Proses pengecekan hasil pengelasan daun propeller $C P P$ 
Suharto dkk /Jurnal Rekayasa Mesin p-ISSN: 1411-6863, e-ISSN: 2540-7678 Vol.16|No.1|123-131|April|2021

Hasil dari perbaikan disimpulkan untuk masing-masing daun propeller membutuhkan $169 \mathrm{~kg}$ bahan isian guna memperbiki daun propeller yang telah rusak. Dari model pengelasan dan teknik perbaikannya tidak ditemukan cacat pengelasan sehingga hasil ini di rekomendasikan oleh klasifikasi Indonesia (BKI). Hal tersebut senada dengan kebutuhan biaya perbaikan sehingga dalam anggaran yang terjadi jika tanpa perencanaan diawal maka memiliki perbedaan sebesar 38\% karena waktu produksi dan penyesuaian yang tidak terulang ulang kembali, sesuai Tabel 2.

Tabel 2. Perbandingan biaya produksi / reparasi

\begin{tabular}{|c|c|c|c|c|c|}
\hline \multicolumn{3}{|c|}{ Dengan Perencanaan } & \multicolumn{3}{|c|}{ Tanpa Perencanaan } \\
\hline No & Pekerjaan & Biaya (IDR) & No & Pekerjaan & Biaya (IDR) \\
\hline 1 & Pelurusan daun propeller & 1.850 .000 & 1 & Pelurusan daun propeller & 1.850 .000 \\
\hline 2 & $\begin{array}{l}\text { Pembersihan dan perapian daun } \\
\text { propeller }\end{array}$ & 1.850 .000 & 2 & $\begin{array}{l}\text { Pembersihan dan perapian daun } \\
\text { propeller }\end{array}$ & 1.850 .000 \\
\hline 3 & Pengeboran bagian yang retak & 500.000 & 3 & Pengeboran bagian yang retak & 500.000 \\
\hline 4 & Persiapan pengelasan / grinding & 500.000 & 4 & Persiapan pengelasan / grinding & 500.000 \\
\hline 5 & $\begin{array}{l}\text { Pengelasan dengan material } \\
\text { tambahan }\end{array}$ & 1.850 .000 & 5 & $\begin{array}{l}\text { Pengelasan dengan material } \\
\text { tambahan }\end{array}$ & 1.850 .000 \\
\hline 6 & Gerinda setelah pengelasan & 500.000 & 6 & Gerinda setelah pengelasan & 500.000 \\
\hline 7 & Pengecekan hasil pengelasan (NDT) & 1.500 .000 & 7 & Pengecekan hasil pengelasan ( NDT) & 1.500 .000 \\
\hline 8 & Penyelarasan daun propeller & 1.500 .000 & 8 & Penyelarasan daun propeller & 1.500 .000 \\
\hline \multirow[t]{6}{*}{9} & Finishing & 500.000 & 5 & $\begin{array}{l}\text { Pengelasan dengan material } \\
\text { tambahan ke II }\end{array}$ & 500.000 \\
\hline & & & 6 & Gerinda setelah pengelasan ke II & 500.000 \\
\hline & & & 7 & $\begin{array}{l}\text { Pengecekan hasil pengelasan ( NDT) } \\
\text { ke II }\end{array}$ & 1.500 .000 \\
\hline & & & 8 & Penyelarasan daun propeller ke II & 1.500 .000 \\
\hline & & & 9 & Finishing & 500.000 \\
\hline & Total & 10.550 .000 & & Total & 14.550 .000 \\
\hline
\end{tabular}

Dari Tabel 2 dapat diketahui jika pekerjaan perbaikan tanpa perencaan maka akan menimbulkan indikasi biaya perbaikan ke II berupa penyamaan geometri sesuai desain awal dan sambungan ulang yang didapati kurang sesuai. Hal tersebut menambah biaya perbaikan pengelasan dan tentunya akan memunculkan biaya pengecekan hasil pengelasan kembali.

\section{Kesimpulan}

Perbaikan propeller memerlukan perencanaan yang tepat dari segi desain dan material yang akan digunakan. Aplikasi penggunaan software desain propeller dapat menganalogikan kriteria karakter performa propeller baik sebelum ataupun sesudah reparasi. Proses pembuatan desain yang paling optimum dari beberapa referensi dapat menjadi gambaran bentuk desain propeller sebelum mengalami kerusakan. Metode perhitungan dengan numerik membantu dalam merekonstruksi desain awal propeller yang telah mengalami kerusakan. Dari hasil perhitungan dapat diketahui jika tegangan yang terjadi maksimum pada saat putaran propeller pada rpm mesin yang optimum. Desain baru 
Suharto dkk /Jurnal Rekayasa Mesin p-ISSN: 1411-6863, e-ISSN: 2540-7678 Vol.16|No.1|123-131|April|2021

sesuai perencanaan dapat memberikan nilai tambahan dari segi kekuatan material dan efisiensi pengerjaan reparasi daun propeller.

\section{DaftarPustaka}

[1] Song S, Demirel YK, Atlar M. Penalty of hull and propeller fouling on ship self-propulsion performance. Applied Ocean Research. 2020;94:102006.

[2] Huang Y, Hu Y, Wu J, Zeng C. Observer-based motion control system for the approach ship with propeller and rudder in the process of underway replenishment. Ocean Engineering. 2021;222:108586.

[3] Oliveira DR, Granhag L, Larsson L. A novel indicator for ship hull and propeller performance: Examples from two shipping segments. Ocean Engineering . 2020;205:107229.

[4] Llull T, Mujal-Colilles A, Castells M, Gironella X. Composite methodology to prevent ship propeller erosion. Ocean Engineering . 2020;195:106751.

[5] Penna N, D'Alessandro F, Gaudio R, Tomasicchio GR. Three-dimensional analysis of local scouring induced by a rotating ship propeller. Ocean Engineering . 2019;188:106294.

[6] Feng D, Yu J, He R, Zhang Z, Wang X. Improved body force propulsion model for ship propeller simulation. Applied Ocean Research. 2020;104:102328.

[7] Sugeng S, Ridwan M, Suharto S, Khristyson SF. Technical and Economic Analysis of Ship Launching with Slipway and Airbag KM. Sabuk Nusantara 72 in PT. Janata Marina Indah Shipyard Semarang. TEKNIK; Vol 41, No 3 (2020): December 2020DO - 1014710/teknik.v41i333710 . 2020 Dec 1.

[8] Utomo B, Khristyson SF. Studi Perancangan Propulsi Kapal Peti Kemas 100 Teus. Gema Teknologi . 2019 Apr 30 ;20(2):46.

[9] Khristyson SF, Jamari, Bayuseno AP. Stress analysis bottom plate block B-03 on patrol ship construction using finite element methods. IOP Conference Series: Materials Science and Engineering . 2021;1034(1):12004.

[10] Khristyson SF, Laksono SH. Analisa Joint Erection Konstruksi Baja Block B05 \& B07 Kapal Patroli Polisi 63 Meter Dengan Mobile Crane 72.000 Ton. Jurnal Proyek Teknik Sipil. 2020;03(1):10-7.

[11] Njaastad EB, Munthe-Kaas NH, Egeland O. Robotic Autoscanning of Highly Skewed Ship Propeller Blades **This work is supported by Oshaug Metall AS and the Norwegian Research Council under the OLIVER project, project number 261639. IFAC-PapersOnLine. 2018;51(22):435-40.

[12] Njaastad EB, Egeland O. Detection and Inspection Planning for Ship Propeller Blades via Spectral Shape Analysis. IFAC-PapersOnLine . 2019;52(10):154-9.

[13] Yusvika M, Prabowo AR, Baek SJ, Prija Tjahjana DDD. Achievements in Observation and Prediction of Cavitation: Effect and Damage on the Ship Propellers. Procedia Structural Integrity. 2020;27:109-16.

[14] Liu Y, Gong Q. Numerical investigation on the flow characteristics and hydrodynamic performance of tandem propeller. Applied Ocean Research . 2020;101:102292.

[15] Blednova Z, Rusinov P. Deformation behavior of a surface composition of materials with shape memory effect in the conditions of multi-factor impacts. Materials Today: Proceedings . 2021;38:1908-14.

[16] Harsha Vardhan D, Ramesh A, Chandra Mohan Reddy B. A Review On Materials Used For Marine Propellers. Materials Today: Proceedings . 2019;18:4482-90.

[17] Haseltalab A, Negenborn RR. Adaptive control for autonomous ships with uncertain model and unknown propeller dynamics. Control Engineering Practice . 2019;91:104116. 
[18] Sukas OF, Kinaci OK, Bal S. System-based prediction of maneuvering performance of twin-propeller and twinrudder ship using a modular mathematical model. Applied Ocean Research . 2019;84:145-62.

[19] Ahmed S, Croaker P, Doolan CJ. On the instability mechanisms of ship propeller wakes. Ocean Engineering . 2020;213:107609. 